KOVALEN]:

\title{
PENGGUNAAN EKSTRAK ENZIM INVERTASE AMOBIL DARI RAGI ROTI DALAM PEMBUATAN SIRUP GULA INVERT DARI NIRA KELAPA
}

\section{[Application of Immobilized Invertase Enzyme Extract from Baker Yeast in The Manufacture of Inverted Sugar Syrup from Coconut Palm]}

\author{
Ida Ayu Made Dwi Yadnyani ${ }^{1 *}$, Syaiful Bahri ${ }^{1}$, Ni Ketut Sumarni ${ }^{1}$ \\ 1) Jurusan Kimia, Fakultas MIPA, Universitas Tadulako, Palu \\ J. Soekarno Hatta Km.9, Kampus Bumi Tadulako Tondo Palu, Telp. 0451- 422611 \\ *)Coresponding author: idayadnyani@yahoo.co.id (hp/fax: +6285242661795)
}

Diterima 17 November 2018, Disetujui 18 Januari 2019

\begin{abstract}
Application of immobilized invertase enzyme extract from baker yeast in the manufacture of inverted sugar syrup from coconut palm has been conducted. The aim is to determine the best hydrolysis time in the inverted sugar production using an immobilized invertase enzymes extract and the effectiveness in reusing the immobilized enzymes. The study used a Completely Randomized Design (RAL) with hydrolysis time variation is $0,3,6,9,12,15$, and 18 hours, and the effectiveness in reusing the immobilized enzymes. The obtained inverted sugar was analyzed using the Dinitrosalisilat (DNS) method at $540 \mathrm{~nm}$ wavelength. The results showed that the best hydrolysis time in resulting invert sugar is 12 hours with concentration of $116.808 \mathrm{mg} / \mathrm{L}$ and it can be reused approximately 3 times with decreasing of enzyme activity equal to $54.93 \%$.
\end{abstract}

Keywords : Coconut Nira, Invertase Enzyme, Enzyme Amobilization, Invert Sugar

\section{ABSTRAK}

Telah dilakukan penelitian tentang penggunaan ekstrak enzim invertase amobil dari ragi roti dalam pembuatan sirup gula invert dari nira kelapa. Tujuannya adalah untuk menentukan waktu hidrolisis terbaik untuk menghasilkan gula invert menggunakan ekstrak enzim invertase amobil dan efektivitas penggunaan ulang enzim amobil. Penelitian menggunakan Rancangan Acak Lengkap (RAL) dengan parameter uji variasi waktu hidrolisis yaitu $0,3,6,9,12,15,18$ jam dan efektivitas penggunaan ulang enzim amobil. Gula invert yang diperoleh ditentukan dengan metode Dinitrosalisilat (DNS) pada panjang gelombang $540 \mathrm{~nm}$. Hasil penelitian menunjukkan bahwa waktu hidrolisis terbaik menghasilkan gula invert adalah 12 jam dengan konsentrasi $116.808 \mathrm{mg} / \mathrm{L}$ dan efektivitas penggunaan ulang enzim amobil yang diperoleh sebanyak 3 kali pengulangan dengan penurunan aktivitas enzim sebesar $54,93 \%$.

Kata kunci: Nira Kelapa, Enzim Invertase, Amobilisasi Enzim, Gula Invert. 


\section{LATAR BELAKANG}

Nira kelapa merupakan cairan tidak berwarna yang duhasilkan oleh bunga kelapa yang pucuknya belum terbuka. Hafidiana (2006), melaporkan bahwa nira kelapa memiliki rasa yang manis karena mengandung sukrosa $15-20 \%$.

Nira kelapa banyak diaplikasikan pada produksi gula kelapa atau gula semut. Nilai jual nira kelapa masih tergolongf rendah, sehingga tidak sebanding dengan biaya operasional produksinya, seperti upah petani gula kelapa. Oleh karena itu, diperlikan suatu alternatif produk lainnya, sehingga dapat meningkatkan nilai jualnya.

Nira kelapa dapat dimanfaatkan sebagai penghasil sirup gula invert. Gula invert adalah hasil dari proses hidrolisis sukrosa menjadi glukosa dan fruktosa dengan bentuk berupa larutan kental (Muchtadi dan Sugiyono, 1992). Terdapat dua metode untuk memproduksi gula invert, yaitu hidrolisis sukrosa menggunakan asam (kimiawi) dan enzim invertase (enzimatik).

Enzim invertase dapat diperoleh dari ragi roti yang mengandung khamir Saccharomyces ceriviseae. Kemampuan enzim invertase dalam hidrolisis sukrosa dipengaruhi oleh kondisi lingkungan, yaitui $\mathrm{pH}$, waktu hidrolisis, temperatur, dan konsentrasi substrat (Syarief et al., 1991).

Bala (2014) melaporkan bahwa waktu hidrolisis terbaik untuk menghasilkan gula invert dari nira kelapa tanpa adanya pengocokkan yaitu pada waktu 24 jam dengan kadar gula invert sebesar 1.145,5 ppm. Razak et al., (2012) melaporkan bahwa faktor pengocokkan memberi pengaruh yang signifikan terhadap kadar gula invert yang diperoleh.

Nilai guna invertase dapat dipertahankan dengan metode imobilisasi karena dapat digunakan berulang. Enzim yang belum mengalami kerusakan struktur selama penggunaan, maka masih dapat dipakai secara berulang-ulang (Soehartono, 1989; Winarno, 1995).

Metode amobilisasi yang digunakan pada penelitian ini adalah gabungan metode penjerapan fisik menggunakan karbon aktif dan metode penjeratan menggunakan alginat. Enzim invertase yang diamobilisasi menggunakan arang aktif dilanjutkan dengan amobilisasi penjeratan menggunakan alginat mempunyai kelebihan berupa enzim tidak mudah mengalami kebocoran dan aktivitas enzim cukup tinggi (Bala, 2014).

Penggunaan ulang enzim amobil dapat menyebabkan penurunan aktivitas enzim yang mengakibatkan konsentrasi gula yang diperoleh menurun. Oleh karena itu, pada tahap akhir penelitian ini dilakukan pengujian untuk mengetahui efektivitas penggunaan ulang enzim amobil untuk dapat melihat kestabilan enzim amobil yang dihasilkan.

\section{METODE PENELITIAN}

\section{Bahan dan Peralatan}

Bahan yang digunakan adalah nira kelapa, glukosa, ragi roti, alginat, pasir, 
kertas saring, ammonium sulfat, $\mathrm{CaCl}_{2}$ 0,01 $\mathrm{M}$ dan $1 \mathrm{M}$, asam 3,5-dinitrosalisilat, $\mathrm{NaOH} 0,1 \mathrm{~N}, \mathrm{NaK}$ tartrat, natrium meta bisulfit, fenol, indikator $\mathrm{PP}, \mathrm{HCl} 0,1 \mathrm{~N}$ dan akuades.

Peralatan yang digunakan adalah neraca analitik, sentrifugator, lumpang dan alu, water bath, kompor, mesin kocok agitasi, lemari pendingin, stopwatch, spektrofotometer uv-vis, hot plate, kuvet, tabung eppendorf, kain saring, aluminium foil dan alat-alat gelas yang umum digunakan dalam laboratorium kimia.

\section{Prosedur Penelitian}

Ekstraksi Enzim Invertase Kasar (Bala, 2014)

Sebanyak 50 gram ragi roti dimasukkan ke dalam lumpang, lalu ditambahkan 50 gram pasir. Campuran ragi roti dan pasir digerus hingga hancur. Campuran ditambahkan larutan $\mathrm{CaCl}_{2}$ $0,01 \mathrm{M}$ sebanyak $50 \mathrm{~mL}$ dan digerus kembali. Suspensi yang dihasilkan dipindahkan ke dalam erlenmeyer $500 \mathrm{~mL}$ dan ditambahkan $250 \mathrm{~mL}$ larutan $\mathrm{CaCl}_{2}$ $0,01 \mathrm{M}$ dan campuran suspensi dikocok selama 30 menit menggunakan shaker dengan kecepatan 250 rpm. Larutan disaring menggunakan kain saring untuk memisahkan filtrat dan residu. Filtrat yang diperoleh disentrifugasi dengan kecepatan 3000 rpm selama 15 menit. Filtrat kemudian ditambahkan ammonium sulfat 65\% dan diinkubasi selama 24 jam. Campuran tersebut selanjutnya disentrifugasi dengan kecepatan 10.000 rpm selama 15 menit sehingga diperoleh endapan enzim invertase kasar. Endapan yang terbentuk dilarutkan kembali dengan $\mathrm{CaCl}_{2}$ 0,01 $\mathrm{M}$ dengan perbandingan 1:10 (w/v) untuk mendapatkan larutan enzim yang digunakan pada perlakuan selanjutnya.

\section{Amobilisasi Enzim Invertase Dengan Alginat (Turah et al., 2017)}

Sebanyak 3 gram alginat ditambahkan akuades sampai volumenya $100 \mathrm{~mL}$, dipanaskan sampai larut. Campuran dibiarkan dingin dimasukkan 10 gram enzim invertase ke dalam gelas kimia yang berisi campuran alginat tersebut. Campuran dibiarkan menetes ke dalam gelas kimia yang berisi $\mathrm{CaCl}_{2} 1 \mathrm{M}$ menggunakan pipet tetes berdiameter kecil sambil diaduk. Campuran didiamkan selama 2 jam sampai gel mengeras. Enzim invertase amobil yang dihasilkan disimpan dalam lemari pendingin sebelum digunakan.

\section{Penentuan Waktu Hidrolisis Nira Kelapa}

Nira kelapa yang telah dipersiapkan sebelumnya dimasukkan ke dalam erlenmeyer $250 \mathrm{~mL}$ sebanyak $100 \mathrm{~mL}$. Nira selanjutnya ditambahkan enzim invertase amobil sebanyak 20 gram, kemudian dikocok di atas mesin kocok agitasi $250 \mathrm{rpm}$ dengan waktu bervariasi, yakni 0 jam, $\quad 3$ jam, 6, jam 9 jam, 12 jam, 15 jam dan 18 jam. Hasil hidrolisis dipisahkan dari enzim invertase amobil, kemudian dianalisisi kadar gula invertnya 
secara spektrofotometri menggunakan pereaksi DNS. Waktu hidrolisis yang menghasilkan gula reduksi tertinggi, dinyatakan sebagai waktu terseleksi dan digunakan untuk penelitian selanjutnya.

\section{Penentuan Efektivitas Penggunaan Ulang Enzim Invertase Amobil (Bala, 2014)}

Penentuan efektivitas penggunaan ulang enzim invertase amobil digunakan waktu hidrolisis terbaik. Enzim amobil digunakan ulang hingga terjadi penurunan aktivitas enzim, selanjutnya kadar gula invert diplotkan terhadap penggunaan ulang untuk mendapatkan persamaan regresi.

\section{Pembuatan Sirup Gula Invert (Luthony, 1990)}

Nira kelapa yang telah dipersiapkan sebelumnya dimasukkan ke dalam erlenmeyer $250 \mathrm{~mL}$ sebanyak $100 \mathrm{~mL}$. Nira selanjutnya ditambahkan enzim invertase amobil sebanyak 20 gram, kemudian dikocok di atas mesin kocok agitasi 250 rpm dengan waktu 12 jam (waktu terbaik). Pisahkan larutan dan enzim amobil dengan cara disaring. Gula invert yang dihasilkan dipekatkan hingga volume gula invert menurun $80 \%$ dari volume awal.

\section{Analisis Kadar Gula Invert Sampel (Chafid dan Kusumawardani, 2010)}

Nira kelapa hasil hidrolisis sebanyak $1 \mathrm{~mL}$ di masukkan ke dalam tabung reaksi dan tambahkan $3 \mathrm{ml}$ pereaksi DNS. Larutan dikocok 5 menit dan dipanaskan dalam air mendidih selama 5 menit lalu dinginkan. Larutan dipindahkan ke dalam kuvet, absorbansi larutan diukur pada panjang gelombang $540 \mathrm{~nm}$. Kadar gula invert sampel ditentukan menggunakan persamaan regresi larutan standar.

\section{HASIL DAN PEMBAHASAN}

\section{Waktu Hidrolisis Nira Kelapa}

Konsentrasi gula invert dari 0-12 jam mengalami peningkatan seiring bertambahnya waktu hidolisis (Gambar 1). Hal ini menunjukan bahwa proses hidolisis substrat sukrosa dari nira kelapa sudah mencapai batas optimum, dimana pada waktu hidrolisis 12 jam semua sisi aktif enzim telah terikat dengan substrat dan enzim sudah jenuh dengan substrat karena jumlah molar substrat melampaui jumlah molar enzim. Waktu optimum dicapai pada hidrolisis selama 12 jam dengan konsentrasi gula invert sebesar $116.808 \mathrm{ppm}$.

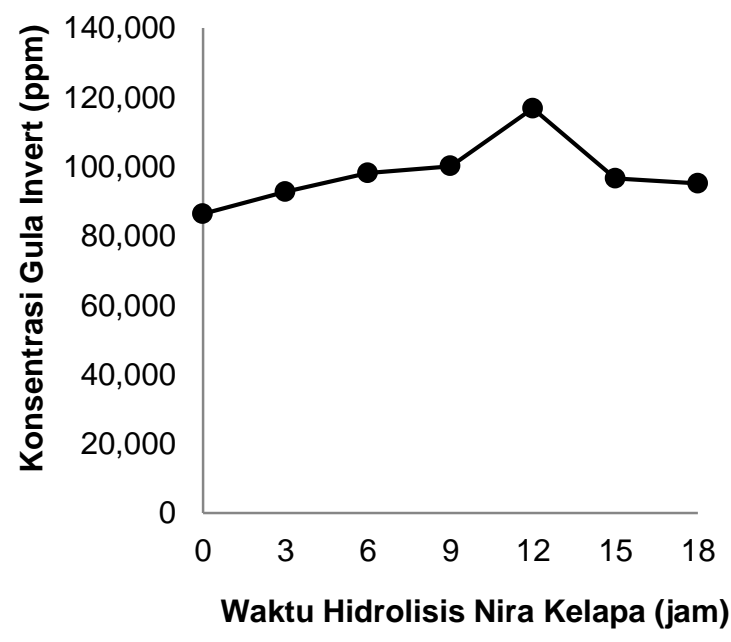

Gambar 1 Waktu Hidrolisis Sukrosa Terhadap Konsentrasi Gula Invert 
Hasil ini lebih tinggi jika dibandingkan dengan hasil yang diperoleh oleh Bala (2014) yang telah melakukan hidrolis sukrosa menggunakan enzim amobil dan memperoleh waktu hidrolisis terbaik yaitu 24 jam dengan konsentrasi gula invert sebesar 1.145,5 ppm. Hal ini terjadi mungkin karena tidak adanya proses pengocokan yang dapat mengoptimalkan proses hirolisis sehingga kadar gula invert yang diperoleh rendah.

\section{Efektivitas Penggunaan Ulang Enzim Invertase Amobil dari Ragi Roti}

Efektivitas enzim yang dihasilkan dapat ditentukan dengan melakukan penggunaan ulang enzim amobil pada waktu hidrolisis terbaik yaitu 12 jam, sehingga digunakan interval waktu 12 jam pada tiap pengulangan. Berikut grafik hubungan kadar glukosa yang dihasilkan terhadap penggunaan ulang enzim amobil.

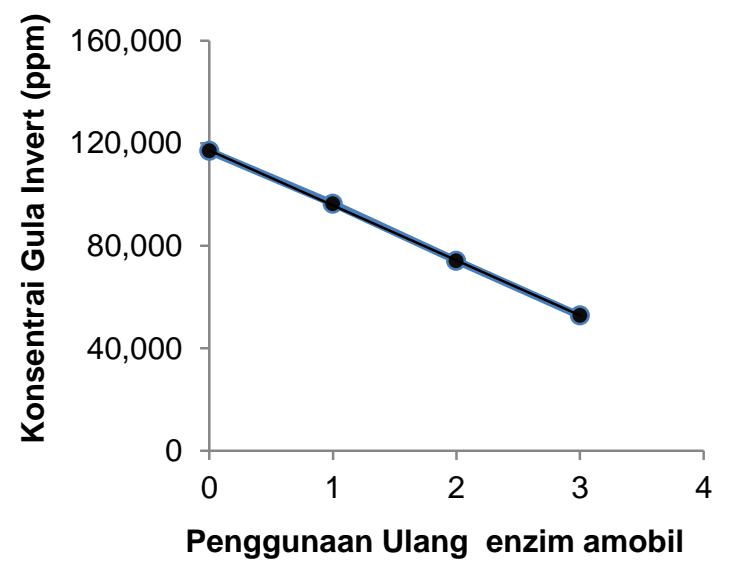

Gambar 2 Grafik hubungan konsentrasi gula invert terhadap penggunaan ulang enzim amobil

Semakin banyak penggunaan ulang enzim amobil maka konsentrasi gula invert yang dihasilkan semakin menurun
(Gambar 2). Hal ini disebabkan karena terjadinya penurunan aktivitas enzim amobil seiring dengan adanya penggunaan ulang. Penurunan aktivitas ini terjadi karena pelepasan enzim dari bahan pengamobil yang digunakan selama pemakaian karena antara enzim dan bahan pengamobil hanya terjadi pengikatan secara fisik (Turah et al., 2017).

Hasil yang diperoleh dari penelitian ini yaitu pada pemakaian ketiga terjadi penurunan aktivitas enzim sebesar 54,93\%. Menurut Bala (2014), terjadi penurunan aktivitas enzim amobil sebesar $33,3 \%$ pada pengulangan kedelapan tanpa adanya faktor pengocokkan. Hal ini terjadi karena enzim telah mengalami kerusakan atau terjadi kebocoran sehingga enzim keluar dari bahan pengamobil. Selain itu adanya faktor pengocokkan dalam proses penggunaan ulang enzim ini juga berpengaruh terhadap butiran-butiran enzim amobil karena sering terjadinya tumbukkan sehingga enzim amobil lebih mudah pecah dari bahan pengamobil dan tidak dapat digunakan lagi.

\section{Sirup Gula Invert}

Berdasarkan SNI 3544 (2013), sirup adalah produk minuman yang dibuat dari campuran air dan gula dengan kadar larutan gula minimal $65 \%$. Volume sirup gula invert yang diperoleh yaitu sebanyak $20 \mathrm{~mL}$ dari volume awal $100 \mathrm{~mL}$ dengan kadar gula invert sebesar 584.876 ppm. 


\section{KESIMPULAN}

Berdasarkan hasil penelitian, dapat disimpulkan bahwa waktu hidrolisis terbaik dalam pembuatan sirup gula invert yaitu selama 12 jam dengan konsentrasi gula invert sebesar 116.808 ppm dan efektivitas penggunaan ulang enzim amobil dalam pembuatan gula invert dari nira kelapa yaitu sebanyak tiga kali pengulangan.

\section{DAFTAR PUSTAKA}

Bala, S. 2014. Kajian Imobilisasi Enzim invertase untuk produksi Gula Invert dari nira Kelapa. Skripsi. Program Studi Kimia. Universitas Tadulako. Palu.

Chafid, A., dan Kusumawardani, G. 2010. Modifikasi Tepung Sagu Menjadi Maltodekstrin menggunakan enzim a-amilase. Skripsi. Universitas Diponegoro. Semarang.

Hafidiana, R. 2006. Inhibisi Aktifitas Invertase Pada Sukrosa dengan Menggunakan Tembaga Sulfat $\left(\mathrm{CuSO}_{4}\right)$. Skripsi. Bogor: Fakultas Teknologi Pertanian Institut Pertanian Bogor.

Luthony, TL. 1990. Tanaman Sumber Pemanis. Jakarta: Penebar Swadaya.
Muchtadi, T. R. dan Sugiono. 1992. IImu Pengetahuan Bahan Pangan. Departemen Pendidikan dan Kebudayaan. Direktorat Jenderal Tinggi Pusat Antar Universitas Pangan dan Gizi. Bogor: Institut Pertanian Bogor.

Razak, A. R., Sumarni. N. K. dan Rahmat, B. 2012. Optimalisasi Hidrolisis Sukrosa Menggunakan Resin Penukar Kation tipe Sulfonat. Jurnal Natural Science, 1(1): 119-131.

SNI $3544 . \quad 2013 . \quad$ Sirup. http://www.sisni.bsn.go.id/index.php/ /sni_main/sni/detail_sni/3946.

Diakses 1 Nopember 2017.

Soehartono, M. T. 1989. Enzim dan Bioteknologi. Bogor: PAU IPB.

Syarief, R., Hermana., dan Chafied, M. 1991. Mempelajari Proses Pembuatan Sirup Gula Invert dari Nira (Arenga pinanta Merr). Buletin Penelitian dan Pengembangan Teknologi Pangan, 9, 20, 17-28.

Turah, N., Bahri, S., dan Nurakhirawati. 2017. Penentuan Waktu Paruh Enzim Amilase Amobil Dari Kecambah Kacang Hijau (Phaseolus aureus) Pada Produksi Glukosa Dari Maltodekstrin. KOVALEN, 3(2):150157.

Winarno, F.G. (1995). Enzim Pangan. Jakarta: Gramedia Pustaka Utama. 